\title{
Relative time-intensity curve: a new method to differentiate benign and malignant lesions on breast MRI
}

\author{
H Sherif, A Mahfouz, A Kambal, A Sayedin*, I Mujeeb \\ From International Cancer Imaging Society (ICIS) 14th Annual Teaching Course \\ Heidelberg, Germany. 9-11 October 2014
}

\section{Purpose}

Benign/malignant overlap exists on time-intensity curve (TIC) of dynamic gadolinium-enhanced breast MRI. This study presents a new method for TIC generation to decrease overlap and improve accuracy.

\section{Material and methods}

MR images of 100 patients with enhancing breast lesions (64 malignant, 36 benign) obtained before and repeatedly after intravenous injection of Gd-DOTA were evaluated. Signal intensity of lesions (SIlesion) and breast (SIbreast) were measured and TIC obtained. Relative signal intensity of the lesion was calculated as (SIlesion-SIbreast)/SIbreast and plotted versus time to obtain relative TIC. Four parameters were evaluated for diagnosis of carcinoma: peak enhancement (PE), initial enhancement slope (S), time-topeak (TTP), and washout ratio (WO). Comparison of parameter performance on TIC and relative TIC has been done by the Student's T test and the Receiver-Operator Curve (ROC) analysis.

\section{Results}

On TIC, TTP has been the only discriminating factor. When threshold for carcinoma has been set at TTP $\leq 2$ min, sensitivity, specificity, positive predictive value, negative predictive value, and accuracy have been 36 , $100,100,43$, and $57 \%$ respectively. On relative TIC, accuracy of TTP has increased to $89 \%$. Area under the ROC curve for TTP has improved from 0.77 for TIC to 0.86 for relative TIC $(\mathrm{p}<0.05)$. WO ratio has become a second discriminating factor on relative TIC with more washout in malignant lesions $(\mathrm{WO}=41 \pm 32)$ than benign

\footnotetext{
* Correspondence: Asayedin0@gmail.com
} Hamad Medical Corporation, Doha, Qatar

(c) 2014 Sherif et al; licensee BioMed Central Ltd. This is an Open Access article distributed under the terms of the Creative Commons Attribution License (http://creativecommons.org/licenses/by/4.0), which permits unrestricted use, distribution, and reproduction in any medium, provided the original work is properly cited. The Creative Commons Public Domain Dedication waiver (http://creativecommons.org/publicdomain/zero/1.0/) applies to the data made available in this article, unless otherwise stated.

\section{and take full advantage of:}

- Convenient online submission

- Thorough peer review

- No space constraints or color figure charges

- Immediate publication on acceptance

- Inclusion in PubMed, CAS, Scopus and Google Scholar

- Research which is freely available for redistribution

Submit your manuscript at Submit your manuscript at C BioMed Central

\section{Biomed Central}

lesions $(\mathrm{WO}=11 \pm 19)(\mathrm{p}<0.05)$. PE and $\mathrm{S}$ were not

\section{Conclusion}

The use of relative TIC improves the discrimination of Cite this article as: Sherif et al:: Relative time-intensity curve: a new method to differentiate benign and malignant lesions on breast MRI. Cancer Imaging 2014 14(Suppl 1):P26. 